\title{
A Linguistic Analysis of Selected Verses in Surat Joseph
}

\author{
Dr. Ibtesam AbdulAziz Bajri \\ Assistant Professor of Sociolinguistics \\ European Languages Department \\ King Abdulaziz University, Kingdom of Saudi Arabia
}

\begin{abstract}
There is more beyond what we could readily hear and see but also about our perceptions about signs and wonders and mental images that correspond to some distinct entities, or to its essential features thus playing an important part in the use of reason or language. This article deals with written messages in the form of verses from the Holy Qur'an. To be specific, we have chosen some verses in Surat Joseph with prevalent usage of signs to accomplish its ends. Under the tradition of Peircean model, semiotic application is broader and fundamental. Given that the Story of Joseph is widely read and reinterpreted several times, we have offered and injected some fresh revelations as spiritually discerned during our research. Any slight variations in/by the 'interpretant' are treated as a welcome development as in all fields of endeavors that further give richness and beauty dependent on cultures, social and geographical diversities. We adhere to the idea that variety is the spice of live, that we have come to learn and accept our differences. However, consistencies are relevant and warranted in areas where interpretation of the attributes of our Creator Allah is concerned - His unlimited love for mankind reigns supreme.
\end{abstract}

Key Words: Semiotics; sign; Peircean model; representamen; interpretant; object

\section{INTRODUCTION}

Qur'an is Allah inspired, revelation and is written in Arabic language and with the passage of time there have been many attempts to translate it, but no one has ever come close to capture the beauty and whole essence of the words except for some approved translations that have passed through rigid screening.

Allah exists and all life including that of people originates from Allah. This goes with Islam's belief that all Muslims must bear witness to the oneness of Allah by reciting the creed, There is no God but Allah and Prophet Muhammad is the Messenger of Allah. This profound statement expresses a Muslim's complete acceptance of and total commitment to Islam. As a Muslim, one has to adhere to five primary obligations, or pillars of faith that must be fulfilled in a lifetime. The five pillars of Islam are Shahadah, Salah, Zakat, Sawm and Hajj. The five pillars define the basic identity of Muslims - their faith, beliefs and practices, and bind together a worldwide community of believers into a fellowship of shared values and concerns. So our faith in Allah is the ultimate reason for living.

To be able to gain sufficient knowledge about Allah's amazing ways we have to read the Qur'an thoroughly. So we think of bringing to light some of the verses that further reveal Allah's mysterious care for those who are faithful to Him as dramatically portrayed in the story of Joseph from the pasture lands of Canaan to the palace of Egypt. We will soon discover how Allah makes all things work together for good that Allah's design is unquestionable. That 
whatever a man plans for his life, the will of Allah prevails that disciplines, transforms and restores us to become a better person.

This study is a simple attempt to contribute whatever spiritual understanding from the point of view of linguistics in general and particularly in the fields of sociolinguistics and semiotics, which "is usually defined as a general philosophical theory dealing with the production of signs and symbols as part of code systems which are used to communicate information" (Tobin, 1990, p. 6). In the Course in General Linguistics, de Saussure has "viewed linguistics as part of a larger social science called semiology derived from the Greek word semeion 'sign'" (Tobin, 1990, p. 23).

First of all, it is our mission to help the helpless, and empower the powerless. We don't always agree on some principles just because they are popular but because they are in line with the teachings of the Qur'an. The final revelation is in fact a way of life as a whole. With the use of language, we as human beings are drawn to communicate with each other. It is the language used that define our social standing. This is quite understandable since we tend to act in accordance with the dictates of society we live in with due regard to already established cultures and tradition. It is through socialization that our culture has been developed, the practices that differentiates or distinguishes us from others. There's always the danger of discrimination and prejudices, social inequality we have to learn to live with. In this modern world, religion plays an important role in shaping the lives of the people. As Sebeok (1978) indicates:

Much has been said about religion, and this may be attributed to the fact that religion offers an explanation for the mental life of man. Indeed, quite frequently, such an explanation takes on as much importance as existence itself. For if we only had accurate and full descriptions of the religious systems of many societies, ancient and modern, we might be able to trace both their cultural and their extra-cultural histories. It is taken for granted here that: (1) Religion is an allencompassing system through which the manifold semantics of human culture and man's experiences can be comprehended. Hence, any religious system tends to be fully comprehending and its categories are those of human experience. (2) Religion is a modeling system; thus, there is no direct correspondence between it and categories of human experience since modeling does not imply mere reflection (p. 232).

How could we be able to interpret the language in use for our project is something we have prayed for. As for our consolation though, we are glad that interpreting the Qur'an is not solely dependent on our intellect and knowledge of grammatical rules of language but we mainly rely on spiritual guidance. The Qur'an is aimed at building relationship between Allah and His creations, thus, written in a language to establish contact as an inherently social process in its natural contexts. Thus, we have to expound some selected verses from Surat Joseph and relate them to their signs not on literal sense but within the context that imply the meaning as it ought to be as in semiotics, because it "illustrates how our capacities to experience the world and interpret ideas, events, and information are processed" (Gaines, 2015, p. 269).

We need to be extra cautious and pray for Allah's guidance. It is human nature to have some weaknesses. But Allah is always around us to guide us through if we communicate with Him through our prayers. Allah wants us to be in constant communication, dependent, and to place our confidence on Him alone. 


\section{SIGNIFICANCE OF THE STUDY}

Semiotics finds its way in this project of study which is an attempt to introduce other means of textual analysis which is more complicated than the conventional discourse analysis or conversation analysis. Before we do that, let us provide some insights of what semiotics can offer to this study. We begin by defining what semiotics means and what it is all about. Taken from Bopry (2002, web), she has noted that, "[s]emiotics is the study of sign action (semiosis)... it is a purely human endeavor. All life forms engage in semiosis, all use signs, only humans know they exist. Only humans engage in inquiry into semiosis or sign activity". Chandler (2007, p. 13) clarifies Peirce's meaning of 'signs':

Indeed, according to Peirce, 'we think only in signs' (Peirce 1931-58, 2.302). Signs take the form of words, images, sounds, odours, flavours, acts or objects, but such things have no intrinsic meaning and become signs only when we invest them with meaning. 'Nothing is a sign unless it is interpreted as a sign', declares Peirce (ibid., 2.172).

According to Swiss linguist Ferdinand de Saussure (1983, p. 66):

A linguistic sign is not a link between a thing and a name, but between a concept [signified] and a sound pattern [signifier]. The sound pattern is not actually a sound; for a sound is something physical. A sound pattern is the hearer's psychological impression of a sound, as given to him by the evidence of his senses. This sound pattern may be called a 'material' element only in that it is the representation of our sensory impressions. The sound pattern may thus be distinguished from the other element associated with it in a linguistic sign. This other element is generally of a more abstract kind: the concept. (Cited in Chandler, 2007, p. 13).

Jappy (2010) goes even so far as to declare that the theories of de Saussure and Peirce of the sign "can be found as theoretical bases of "hundreds or more...studies in theory and methodology...devoted to the complex interplay of vision, images, and culture" (p. ix) (Cite in Nöth \& Jungk, 2015, p. 658). This time however, our linguistic analysis will be using as material the ever popular Story of Joseph in the Qur'an. "The focus is on the reflexive nature of semiotic meaning-making through language, that is, on how a linguistic sign - indexing a linguistic system as a whole - extends into a semiotic sign" (Ivković, 2015, p. 90). Our concern covers how people speak and interact with each other, how meanings are created and how they become socialized through the use of language. The way people use language signal their social background, their sense of inclusion or distance, or their sense of power or powerlessness.

And one may ask why semiotics application is significant in this project study? Upon reading the verses about the story of Joseph in Qur'an we cannot deny the fact that there are lots of insights and revelations by means of signs such as that we are amazed how an ordinary young boy Joseph could handle the circumstances, the trials and able to survive it all. Then we realize that the life of Joseph is full of signs and wonders (as Allah wills it) which could well be highlighted in our analysis using the theoretical work and model of the sign, of semiotics, and of the taxonomies of signs as formulated by the pragmatist Charles Peirce. We have favored the model of the signs that has been forwarded by Peirce instead of Saussure as it's an approach easier to apply and understand besides it's more appropriate for our material. Besides, "while Saussure may be hailed as a founder of semiotics, semiotics has become increasingly less Saussurean since the 1970s" (Chandler, 2007, p.10).Though both models draw parallels between Saussure's signifier and Peirce's sign/representamen, these are not perfect analogies. Ogden (Web), a zoobiographer is quick to note that "[t]here are differences between the two - 
for example, Peirce's sign is a much broader category than Saussure's signifier, as it extends to the physical world".

Again, why we bother to study and explore this intriguing subject on semiotics? Are we going to enjoy or appreciate, or better yet shall we benefit from it? Quoting from the author Chandler (2007) puts it that, "studying semiotics can assist us to become more aware of the mediating role of signs and of the roles played by ourselves and others in constructing social realities. It can make us less likely to take reality for granted as something which is wholly independent of human interpretation. Exploring semiotic perspectives, we may come to realize that information or meaning is not 'contained' in the world or in books, computers or audio-visual media. Meaning is not 'transmitted' to us - we actively create it according to a complex interplay of codes or conventions of which we are normally unaware. Becoming aware of such codes is both inherently fascinating and intellectually empowering. We learn from semiotics that we live in a world of signs and we have no way of understanding anything except through signs and the codes into which they are organized ... To decline the study of signs is to leave to others the control of the world of meanings which we inhabit" (pp. 10-11).

There we have it about semiotics!"[A]n understanding of semiotics can enhance the logical thinking and effective communication of science, advertising and marketing, politics, education, and all forms of storytelling, as well as informing critical thinking in audiences and the general public" (Gaines, 2015, p. 297) .We can no longer question the wisdom charged on us by these semioticians and we should be grateful that during and after the research study we feel more aware of the things happening around and about us. It provides challenges, confidence and opens doors and venues for more opportunities which are more or less limited by our lack of ideas and knowledge in general. This for us is the most significant consideration in undertaking this project study on the life of Joseph as meaningful and colorful as his garment - the understanding of the relation between sign and the object.

If we go with the most basic definition of semiotics as the study of signs, there is something more beyond as to what it involves. One of the broadest definitions of semiotics is that of Eco (1976) who states that "semiotics is concerned with everything that can be taken as a sign" (p. 7).

In an article written by Gorny (Web), he offers at least three types of definitions for semiotics. His second definition is the one which strikes us the most, as he asserts that:

"Semiotics is an application of linguistic methods to objects other than natural language." What does this mean? It means that semiotics is a way of viewing any thing as constructed and functioning similarly to language. This "similarly" is the essence of the method. Everything can be described as language (or as having a language): the system of kinship, card games, gestures and facial expressions, the culinary art, religious rituals and behavior of insects. We can see that semiotics is a transfer of the metaphor of language onto any non-linguistic ... phenomena.

As we have said, linguistics involves diverse interdisciplinary disciplines, thus; it follows that our analysis shall interconnect with each other in more or less coherent way. We can combine psychology with philosophy which deals with logic. It is found that early Psychology evolved out of both philosophy and biology. Today, psychologists prefer to use more objective scientific methods to understand, explain and predict human behavior. 
Human beings do not merely exists and act on instinct but a gradual development of understanding most of which generate from interaction with each other. We are even called social beings with the use of language which has become the medium of expression.

The significance of this study cannot be overemphasized which can be varied from one individual to another person or group. To relate the story of Joseph with our lives as Muslims, we are united and ought to have firm belief in the oneness of Allah. We have to be submissive to Allah's will and we have no right to complain. Conflicts do arise as long as we live, but as we go through with life, we will be able to handle any circumstance no matter how unpleasant could be as long as have faith in Allah. Most important of all we know that there is Allah who is in control of everything.

A classic example revolves around the life of Joseph who has suffered persecution, injustice, is tempted but firmly holds on to his belief and faith in Allah. In the end the design of Allah is revealed showing the mysterious ways how the Almighty moves and works in our lives for our own good.

Hence, we can ask the question concerning a Peircean triadic definition of the sign (representamen, interpretant, and object) and how far we can apply his definition on the selected verses of Surat Joseph. Moreover, we have to reflect on the following queries to be able to provide answer as necessary. We could find the answers in the analysis section of this study. However, it may come not in sequence but for us to find out that could be read between the lines. The questions have posed are not to preempt whatever notion is running on your mind but help to build up deeper insight and develop our sense of connection with the main characters through the selected verses on the story of Joseph. After reading the analysis, you will be ready to form our own opinion as we reflect deeper on the life of Joseph. As for us, we have done just enough to come up with our own answers. Thus, your rejoinder is herewith solicited on the following grounds if you were on our shoes:

a) What made us decide to interpret further the already familiar Surah on the life of Joseph (Peace Be Upon him)?

b) Who are the key players involved in this beautiful drama of life?

c) What makes it special to read about Joseph's life and its relevance in this present day or real world?

d) Why do we consider it relevant the awareness we can get from learning the series of events within which the context is reduced to show the mysterious ways in which the hand of Allah works in one's life?

It is therefore if great significance to correlate our life with what we are about to read in the analysis of the verses. We may draw an inspiration or encouragement based on the life of Joseph, that if we are faithful to Allah we will reap the reward in store for us.

\section{METHOD OF ANALYSIS}

In this project study, we will be using Peircean triadic definition of the sign, and his general typology of signs. Chandler (2007, p. 29) Peirce's triadic (three-part) model is consisting of:

1. The representamen: the form which the sign takes (not necessarily material, though usually interpreted as such) - called by some theorists the 'sign vehicle'.

2. An interpretant: not an interpreter but rather the sense made of the sign.

3. An object: something beyond the sign to which it refers (a referent). 
In Peirce's own words:

A sign ... [in the form of representamen] is something which stands to somebody for something in some respect or capacity. It addresses somebody, that is, creates in the mind of that person an equivalent sign, or perhaps a more developed sign. That sign which it creates I call the interpretant of the first sign. The sign stands for something, its object. It stands for that object, not in all respects, but in reference to a sort of idea, which I have sometimes called the ground of the representamen" (Peirce 1931-58, 2.228).

Semiotics involves the study not only of what we refer to as 'signs' in everyday speech, but of anything which 'stands for' something else. "Moreover, it is important to emphasize that the form communicated from the object to the interpretant through the sign is a regularity, a "habit" that allows a given semiotic system to interpret that form as indicative of a class of entities, processes, phenomena, and thus, to "answer to it" in a regular way" (Queiroz et al, 2008, p. 80).

Chandler (2007, p. 36) notes that, Saussure has not offered a typology of signs, while Peirce (1931) offers several ones. He adds a citation of Hawkes (1977, p. 129) "[a]lthough it is often referred to as a classification of distinct 'types of signs', it is more usefully interpreted in terms of differing 'modes of relationship' between sign vehicles and what is signified" (p. 36). He continues that "[i]n Peircean terms they are relationships between a representamen and its object or its interpretant" (p. 36). Gaspard (2015, p. 553) adds more clarifications according to the classical pragmatist terms:

[T] he concept of Interpretant allows meaning to be considered as something not immanently fixed (i.e., the obscure signified), but as an effect of signs dependent on a context. Thus, with Eco (2014: 90), we consider that "interpreting [an] expression in context means magnifying certain interpretants and narcotizing others, and narcotizing them means removing them temporarily from our competence, if only for the duration of the current interpretation."

Nuessel (2008, p. 346) in his review article 'interpretive semiotics' cites the co-authors Petrilli and Ponzio (2005) summary of Peirce's triadic sign as:

According to Petrilli and Ponzio, Peirce's triadic sign involves the following elements:

(1) something objective (not necessarily a physical object), pre-existent, autonomous, in this sense 'material' with respect to interpretation (the Object, in Peirce's terminology); (2) the interpreted, that is, this same object insofar as it 'has meaning' (the Sign, in Peirce's terminology); and (3) the interpretant, through which the object receives a given meaning. (p. 7)

Moreover, Hilpinen (2015) explains Peirce's terminology of semiotics as "we can say that a sign which connotes some of its own qualities may be regarded as an icon in the strict or narrow sense of the word, and any connotative sign has iconic interpretants as part of its sense. A sign can create in the mind of an interpreter an iconic sign which enables him to identify or recognize the object of the first sign without having that icon as part of its sense" (p. 1000).

To offer our readers valuable insights into the heart of Qur'an, we need to acquire sufficient knowledge about the following taking into consideration context of the selected verses in order to understand them. Therefore, we need some knowledge about the Arabic language and its constructions of the selected verses, their processes of translation, the literary genres, and the literary contexts. 
The task of undertaking this project with the application of semiotics is given granting that the story of Joseph is loaded with signs and their representations. Therefore, "the more information one can bring to bear on the process of interpreting, the closer one can come to the dynamical object of the sign" (Metro-Roland, 2009, p. 274). It is a bold step from our earlier research projects which are less complicated. Thus, it serves as a challenge to devote time for a project deemed interesting due to the fact that Qur'anic version as source reference is quite famous and special. It is true that the story of Joseph has been given a complete chapter in the Qur'an meant to show that it is extraordinary. As a matter of fact, there are already many commentaries from various groups with its own respective agenda. The significance of each and every commentary is understandable without any pretention but to show legacy and implication in real life the story of Joseph has had to its readers. It just proves to show that a good narrative will continue to count admiration from one generation to the next. The narrative clearly reveals how prophet Joseph is able to accomplish all that has been prophesied whether it comes as a vision through his own dreams and of others. We cannot set aside speculations coming from non-believers but the signs and wonders are the mysteries of our sovereign Allah Who is in control of everything.

The story of Joseph brings to light the existence of Allah as the master of all things in the universe. HE is the real author of Qur'an and of course of this particular story as retold to prophet Mohammed. After overcoming all trials in life, the victories of Joseph have not changed him. Instead, he has become more forgiving to his brethren and loving son to his aged father Jacob till the end. According to Peirce famously claim analysis, this maturity of good feelings is a sign of 'symbol grow' and according to Hoffmeyer (2015) a symbol of scaffolding grows of mind. Hoffmeyer (2015) explains that "[t]he point here is that semiotic scaffoldings not only facilitate temporal stability, they also afford "spatial touch points" in the semantic topology of the sign system. Such touch points enable human symbol users to intelligently discuss abstract, counterfactual and multiply referential meanings, and by so doing the scaffolding itself, as scaffolding, becomes configured into new scaffoldings thereby facilitating the process whereby "symbols grow"" (pp.156-7).

Here we offer our share of analysis in our own humble and honest attempt to portray the signs and wonders that really matter to us. Though we are well aware of the translations in Qur'an, we have relevant fresh revelations as a fruit of our labour that has come up during and after the research is done.

Since we will be using the semiotic model preferred by Peirce, one will find that signs are best understood as physical objects rather than words,. There may be overlapping due to application of sub-fields of linguistics such as philosophy and sociology, but will be done so in harmonious manner one could hardly sense the shifting consistent with the logic required under each circumstance. It helps to be both objective and subjective in this kind of study as the situation so warrant. We need to have a firm grip on what's applicable either to be objective or subjective at the same time.

There is nothing insignificant in Joseph story right from its inception to the end. The concept is well taken care of in the Surah that contextualizing is a must to further appreciate the inside story as a whole. 


\section{ANALYSIS OF THE STUDY}

According to Chatman (2004) there are two types of events. The first one is the one called Kernels events which are the core events of the story that move forward and the other type is Satellites which are secondary events that revolve around the Kernels and they remain very bound with them that they cannot be explained or improved without them (Cited in Al-Qurashī , 2004, p. 12). Thus the series of both types of events in the life of Joseph come in sequence, therefore we maintain as much as possible to present our analysis in chronological manner as presented in the targeted Surah. However, as the Qur'anic version of the story is moving there are events that correlate to and fro and that there's tendency to overlap. Therefore, one may wonder why this is not prevented as we let our intuition flow in no particular order. The main point here is that there is story inside the story of Joseph that makes it appealing to readers. This is a narrative coming back to life as if it is happening right in front of our very eyes. An outline is necessary to pattern our presentation of the Surah as it has occurred.

With this in mind, we hope to give justification where the concept seems to imply that view leads one to another viewpoint. We have no pretensions whatsoever that we are well acquainted with the subject but we have done a lot of readings right from the Qur'an, the commentaries, narrative as well as analysis of respected authors.

As necessary, we will make use of Abdullah Yusuf Ali's The Holy Qur-ān: English Translation \& Commentary (With Arabic Text) (1934) as well as Peirce's model of semiotics as an approach to our textual analysis to unveil and relate the meaning of the signs. Therefore, we will be able to "[f]orcing the reared to deduce what is missing" (Dennis, 2004, p. 12). The insistence on predicting the missing or what is between lines or beyond them is the source of analytical pleasure and the source of depth of connotations. It is the main source of aesthetic textures create by these missing elements and the textual transmission gaps (Al-Qurashī, 2004, pp. 3031).

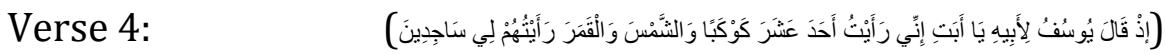

Behold, Joseph said, To his father: "O my father! I did see eleven stars And the sun and the moon:I saw them prostrate themselves To me! (pp. 550-1)

Context: The dream of Joseph for the stars, sun and the moon bowing in prostrate to him.

- The representamen : the heavenly bodies that points to the kingdom of Allah

- The object : seeing the stars, sun and moon in a dream

- The interpretant : Jacob sees with prophetic sense clearly what the dream really means. It means that his favorite son Joseph will someday become great and lord over the family including him. But he has a wisdom that to divulge the dream will cause trouble for young Joseph from his brothers who intend to do harm out of jealousy. So he has tried to shield Joseph while advising him to keep it secret for the meantime.

What are those objects stand for? They have their actual existence as part of Allah's creations. First, reflect on our awareness that the stars, sun and the moon are part of heavenly bodies located way up high in the sky. But each of them has its own position and function in the universe. The moon no matter how big or visible is dependent on the sun for its light, while the stars though seemingly small are great in numbers but in the dream the stars are numbered exactly as the total number of his eleven brothers. This alone has specific meaning and the manner it appears to Joseph is that he will be playing dominant rule on earth as it is in heaven. 
Jacob, on the other hand, has had accurate interpretation which invites his "responsive behavior" (Jensen \& Pedersen, 2016, p. 85), but he fears that this may cause trouble for Joseph has he relates this dream to his brethren. Jacob's "direct perception and affordances helps [him] to look more closely at the entanglement of cognition and emotion as a complex process constituted by feedbacks of many shifting components"(Jensen \& Pedersen, 2016, p. 100).

So being a wise father that he is, he has cautioned Joseph against telling this dream to brothers and thus, he keeps it to himself. Further, Jacob tells Joseph that Allah has had chosen and taught him the interpretation of dreams among other things as Allah alone can confer knowledge and wisdom.

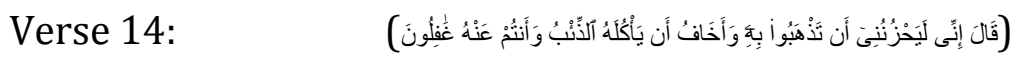

(Jacob) said: "Really It saddens me that ye should take him away: I fear lest the wolf Should devour him While ye attend notTo him." (p. 553)

Context: The wolf and the sacrificial lamb (the wolf story)

- Representamen : a wolf as we know its general characteristics

- Object : the impression or physical attributes of a wolf

- Interpretant : though hesitant Jacob may be he has no power to control his older sons to take Joseph away from him. When all he could do is to say a big no to their pleadings, yet it's as if things bound to happen. And worst it is also Jacob who gives them the idea how to create an excuse when their evil scheme will be implemented.

We could likened Joseph as the lamb while his brothers are the wolf. Both animals are figuratively used playing important role to portray how the two opposite characters are introduced in the plot. When there's a sheep there must be a shepherd that could be Jacob who will not be around Joseph all the time. Here Joseph is portrayed as sheepish while his brethren are considered a pack of wolves ready to devour their prey. The lamb represents obedience to the will of its master no matter what he wants to do. An innocent young Joseph who has least idea of what is brewing inside the family, the envy and hatred towards him yet seemingly naïve though considered a smart and bright lad.

Though the father has unwittingly provided the idea that a wolf might prey on him, this has become an easy alibi for the brothers to get off the hook. What an escape goat the wolf might have been but Jacob has doubted them and considered their reasoning as only a tale. But Allah lets this to happen to Joseph as a way to play out the design purposely is made for him, to serve as a sacrifice for future restoration and deliverance.

We could just imagine how sad and fearful Joseph might have been when thrown into the pit. Full of darkness with little air moving that makes him hardly breathe but this doesn't deter him to survive. As we go through with this context we feel dread with his situation. But he's not like the boy who cries wolf as there is none except his brothers.

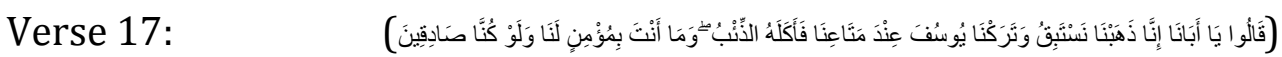

They said: "O our father! We went racing with one another, And left Joseph with our things; And the wolf devoured him....But thou wilt never believe us Even though we tell the truth.

Verse 18:

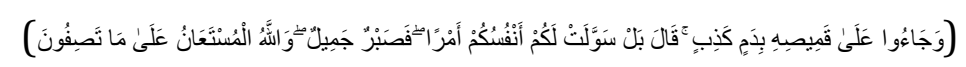


They stained his shirt With false blood. He said: "Nay, but your minds Have made up a tale (That may pass) with you. (For me) patience is most fitting: Against that which ye assert, It is God (alone) Whose help can be sought"... (pp. 554-5)

Context: A multi-colored garment given by Jacob to his favorite son Joseph has been defiled.

- Representamen

- Object

- Interpretant all. Immediately after seeing the stained shirt he has passed judgment on his sons that it isn't true. That he should be patient within himself believing that Allah alone has the answer.

Garment stands for many things but literally is used for clothing to cover or adorn ourselves. The way we wear could make us vain or how we carry it could change the way people look at us. However, it's only external outfit we cannot attach conclusive meaning unless we don't like the person wearing such garment. And this is the case of Joseph whose brothers are already jealous and hated him.

Foremost, the garment is given just to Joseph to inflame the envy of his brothers. Obviously, the father is playing favorites whether on purpose is beyond question. Jacob is quite aware what trouble this might bring to his favorite son yet he is determined to give it just the same not thinking about the implications. Abū Hamdah (1985) indicates that this garment is a blessing one, and might be worn by Ishaq and then given to Jacob who in return has given it to Joseph to wear it under the external one. When Jacob has seen the external garment tainted with false blood without seeing the internal one, then he does not believe that the wolf has eaten Joseph. Therefore, he concludes that Joseph and his blessing internal garment are safe (pp. 36-7).

We could see here a hand working behind Jacob why he's not cautious enough to endanger the life of Joseph. There is a purpose Allah wills him so, so that He could show His workings and designs for mankind using Joseph as an instrument. Jacob is made an instrument through Joseph already made perfect beforehand. But Joseph is ready to accept whatever fate coming his way.

It's not Joseph's fault that his father has given him a coat for he does not ask for it. It would have been a different situation if Joseph has been proud wearing for display in front of his brethren.

This garment becomes one of the most celebrated object which easily becomes the reason or an alibi when the brothers conspire to make it appear he is devoured by a wolf. The garment is defiled with lame excuse though not a perfect scheme to fully convince Jacob. The garment is soaked with a blood of a sheep though there's no any trace of mutilations appear so it's unbelievable. There really no such thing as perfect crime. Under this circumstance Jacob smells something fishy while he has been given slightest hope that Joseph may still be alive and that someday would show himself up.

Verse 21:

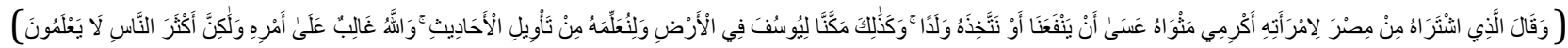

The man in Egypt Who bought him, said To his wife: "Make his stay (Among us) honourable: Maybe he will bring us Much good, or we shall Adopt him as a son." (pp. 556-7) 
Context: The battleground where the story moves and where the real action has taken place.

- Representamen : actual playground \& spiritual battleground

- Object

- Interpretant : The high court official is used as an instrument by Allah for a more 'pleasant' and honorable stay of Joseph in Egypt. In the final analysis, Egypt has played a major role for his victories when he has successfully hurdled all obstacles and trials. Joseph is predestined by Allah to become great in Egypt as he has performed well in the hands of the rich, famous, and powerful officials of the land.

- It appears as though as simple as if Joseph is sent to Egypt by Allah's design to be sold as a slave and later imprisoned in Egypt. But in fact, it is in Egypt that Joseph's family expand into a nation. In spiritual realm, Allah clearly demonstrates His sovereignty, Who is in complete control of everything.

- Most people know the story how Moses has confronted Pharaoh and commanded him to 'Let my people go'. But it's the story of Joseph that shows us how and why the family of Joseph has got to Egypt in the first place. Looking back, the story of Joseph forms an important bridge between the patriarchs (Abraham, Isaac and Jacob) and Moses.

Joseph has been lucky to be 'purchased' by a high court official in Egypt who is called 'the Aziz' who shows great interest in him seemingly without any malice. He therefore becomes a prized 'ownership' of his influential master. The words describe in the verse are meant to entice and please Joseph hoping that he might bring more honor, dignity and power to the owner's household someday.

This beautiful and historical land of Egypt is prominently featured in this particular story of Joseph. The story lends credit to Egypt with its strategic location complete with necessary influential characters and scenery. It is here where Joseph has been victorious and demonstrates his talent, shown his good traits and behaviour not to mention his natural beauty. Even during the times of Abraham, and even the prophets before Mohamammed, and where Moses has spent his childhood until the time of deliverance of the Israelites deliverance out of Egypt, this country is been blessed serving as playground and spiritual battleground where our Allah shown His might.

In Egypt, all the trials and victories of Joseph is played out as he puts himself against the rich and influential people. The hand of Allah is always at his side throughout his ordeals. He is gifted by Allah with necessary temperance, self control and perseverance to withstand the trials and crisis all taking place round him. He shuns undue favor and not succumbing to temptation for earthly pleasure. At the end he is vindicated by those very people who has accused and trampled his character.

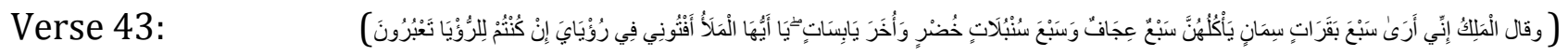
The king (of Egypt) said: "I do see (in a vision) Seven fat kine, whom seven Lean ones devour, and seven Green ears of corn, and seven (others) Withered. 0 ye chiefs! Expound to me my vision If it be that ye can Interpret visions." (p. 566)

Context: The interpretation of dreams by Pharaoh

45. Representamen : the interpretation of two set of dreams as one

46. Object : the dreams (seven fat/lean cows whom seven lean ones are devouring followed by seven green ears of corn and seven others dry 
47. Interpretant

: Joseph's convincing and accurate interpretation of dreams have paved the way for Pharaoh to promote and confer the highest position of the land only next in command after the king.

48. Dreams speak in symbols, a language far better than words at conveying understanding. Words are heard or seen in an intellectual way. Symbols are felt and experienced in an intuitive way. But let us not wonder why Joseph has been always successful in the interpretation of Pharaoh's dreams. Because he first prays for guidance of Allah whom he trusts, otherwise nothing could be derived if he only relies only from his own knowledge and understanding.

Again the hands of Allah is with Joseph since the dream is not of his own or else it would be difficult no one will believe or listen to him. We at most times do not remember dream images but have a clarity of consciousness on the matter as we awaken. Sometimes the message will be obvious to us, other times we need to use our intuition. One thing is sure after this analysis, that Allah even in our sleeping is watching over us and gives us blessings.

A confused medley of dreams really but with Joseph who is gifted by Allah to interpret dreams and visions, the dreams are given accurate meaning that pleases the king so much. Thus, the king said,

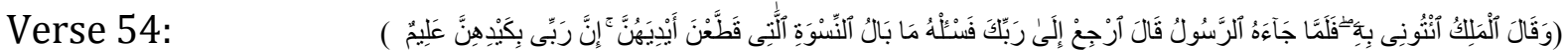

"Be assured this day, Thou art, before our own Presence, With rank firmly established, And fidelity fully proved!" (p. 571)

The dreams come in two sets but analogous in a way that seem to be understood as one. The wisdom here for having twin dreams is for memory retention and emphasis that such dreams are really meant to tell something. First, there are dreams, then the dreamer. At an appropriate time, Allah knows whom to use as instrument for perceived restoration and salvation of mankind. In actuality, the Pharaoh is the dreamer since he is the one who has dreamt. But further analysis reveals that Joseph is the dreamer in the real meaning of the word. We don't play mind games but the word dreamer here has become an adjective not a noun. Joseph's interpretation comes out from his belief and faith in Allah that could only be given to him after spending time in prayer. Most of us could only understand or relate ourselves to the dream if it comes true afterwards.

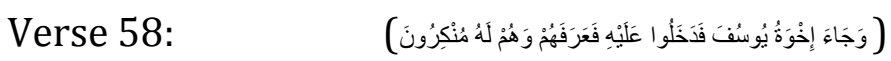

Then came Joseph's brethren: They entered his presence, And he knew them, But they knew him not. (p. 572)

Context : Meeting some of the brothers after a long time

- Representamen : controlled emotions

- Object : face to face with the brothers

- Interpretant : How does Joseph able to control his emotion? So many wicked things have been inflicted on him by his older brothers. And yet Joseph resists evil and it must have been difficult to restrain himself when he has the upper hand and the power to crush his helpless siblings. However, he doesn't do them any harm, and it's worth asking and knowing why.

We offer the reasons why Joseph is able to control his emotion: It's because Joseph still loves his brothers. Most of all, he puts Allah at the center of his life, and he trusts Allah's plan. 
The brothers are unaware that it is their own brother Joseph who is in front of them means that they are blinded by their own folly. Not unless a major face change does happen since young Joseph is last seen by them, then it could be possible. Perhaps Joseph's countenance looks mature of his age because of great responsibility and that's it. Who would have ever thought that Joseph could rise to the highest position. It's far from their mind and any thought of striking resemblance to their hated brother will be dismissed outright. He, the boy who has been sold for a measly amount as slave, quite impossible isn't it? But with Allah, there's really nothing that is impossible!

They might have insinuations that this high ranking officer is their long lost brother but their guilt prevents them to see otherwise. They look at him lording over them in such gentle and hospitable manner yet they don't wonder why. What makes them special to be treated like that is enough to make one suspicious, isn't it? Perhaps it's too premature yet to introduce himself at this early stage as the drama is just beginning to unfold.

However, Joseph has another thing in mind. He wants to be what Allah wants him to be as a generous and forgiving person. Allah is directing Joseph to treat his brother so well. What a sweet revenge indeed, to treat evil with kindness. He has controlled his bottled emotions against his brothers, the fact that he cries in privacy after seeing them. The hurts of the past have grieved Joseph but this is just another step in the healing process when he finds a private place to weep and release any anger in his heart. Behind a deep anger is a longing and love for his brothers.

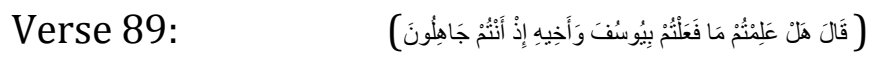

He said: "Know ye How ye dealt with Joseph And his brother, not knowing (What ye were doing)?"

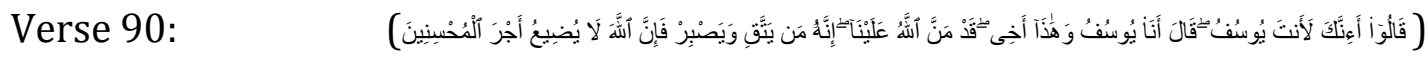

They said: "Are thou indeed Joseph?" He said: “I am Joseph, and this is my brother: God has indeed been gracious To us (all): behold, he that is Righteous and patient, -never Will God suffer the reward To be lost, of those Who do right." (pp. 583-4)

Context : Joseph's confrontation and at the same time exhortation about Allah's grace and faithfulness is extended also to all his brothers where forgiveness and love prevail.

49. Representamen : action and reaction with thanksgiving for Allah's grace

50. Object : unveiling the mask of the real Joseph

51. Interpretant : The confrontation could have been dramatic for them all. But Joseph's winning demeanor has made them feel comfortable with each other. Thus, the opportunity arises to exhort the brothers about the grace of Allah not only for him but also to them all. Notice the word 'us' which is all inclusive. This shows Joseph's pure and generous heart showing magnanimity in power. And the brothers could only listen intently while Joseph exhorts about fear and obedience to Allah by following all His commandments.

- We could envisage here a scenario where Joseph embraces his brothers and with each other for comfort and the joy that Joseph found forgiveness in his heart so that all fears and apprehension vanish right away. They must be thankful to Allah for their newfound hope for the future because of Joseph. 
As I write this analysis, my heart is beating fast being carried away by mixed emotions. Emotions of joy, happiness and amazement and sadness. And who wouldn't be if you imagine yourself as one of the brothers but not as Joseph. Remember that Joseph already has his moments of success, of ups and downs yet manages to stay on top. But for the brothers, we can relate to their struggles from past wrongdoings and yet they find forgiveness from the very person who feeds them now. Sadness and guilt from the pain inflicted on Joseph. But at that moment, with Joseph they see security, abundance, hope and most of all will be blessed by Allah that Joseph worships. As a matter of fact the brothers respond in:

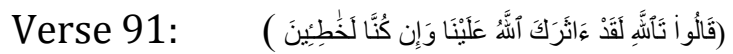

They said: "By God! Indeed Allah has preferred thee Above us, and we certainly Have been guilty of sin!" (p. 584)

The brothers cannot believe their eyes, right in front of them is their brother Joseph who becomes a high ranking officer. The sheer acknowledgement of themselves as sinners is a testimony that they are ready for the consequences of their past misdeeds. But they are already forgiven even before asking forgiveness from Joseph for he is noble of heart and mind as willed by Allah.

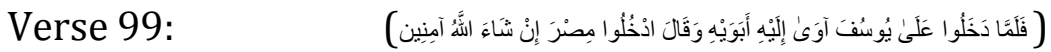

Then when they entered The presence of Joseph, He provided a home For his parents to himself, And said: "Enter ye Egypt (all) in safety If it please God."

Verse 100:

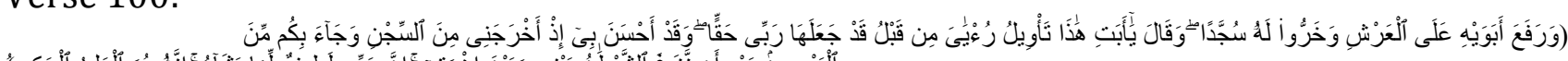

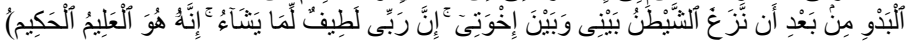

And he raised his parents High on the throne (of dignity), And they fell down in prostration, (All) before him. He said: "O my father! this is The fulfillment of my vision of old! God hath made it Come true! He was indeed Good to me, when He Took me out of the prison And brought you (all here) Out of the desert, (Even) after Satan has sown Enmity between me and my brothers. Verily, my Lord understaneth Best the mysteries of all That He planneth to do. For verily He! Only He is full Of Knowledge wisdom. (pp. 586-7)

Context: The family reunion and realization of Joseph dream as a young man. From pit to prison, and finally to palace.

- Representamen

- Object

: fulfillment of Allah's promise to Joseph

and the moon to bow in prostration before him

- Interpretant : This is the story inside a story where Jacob's family is restored intact by Allah in Egypt due to Joseph faith and trusts in Allah. He follows Allah's plan neither thinking nor knowing the fulfillment of his dream will even come true. He is quite aware about his own dream and it's interpretation as intimated to him by Jacob when he is still of innocent mind. For Joseph it is just a dream, though he might be aware that he's getting near to the realization of his dreams. We also give credit to Jacob, the family patriarch who holds the family together with his patience despite some disagreements with his sons. By Joseph's acknowledgement in Verse 100 that "For verily He! Only He is full Of Knowledge wisdom" affirms his firm belief and personal relationship with Allah. 
We read here a young man Joseph with pure heart not corrupted by power and trappings of wealth and comfort. He is all the more humble and does not forget to acknowledge what Allah does not only for him but for the entire family. He is grateful that he is chosen by Allah and able to restore unity in the family.

The reunion has been the happiest moment in Joseph's life because of the fulfillment of the dream and also because he has not lost the love he has for his brothers despite their treachery. He finds forgiveness in full measure, and with no reservations. He prefers only to use the deictic demonstrative pronoun "this" in "O my father! This is the fulfillment of my vision". Brandt (2016) says that this type of deictic effect is in itself a deictic act "most often intended to let the speaker or someone else know that you find the conveyed content of the speech less than useful ... that carries a message, and the message again contains an indication of something the receiver should attend to. Such semiotic acts often use signifiers with little direct relation to their indicative signified indication" (p. 1). Brandt (2016, p. 2) adds:

they both point and contain indications, they have often been associated with the index, a semantic sign type suggested by philosopher C. S. Peirce, a sign opposed to icons and symbols. Indexical signs, or indices, are signs "whose relation to their objects consists in a correspondence in fact" (Peirce 1982: 56).

Al-Qurashī also (2004) mentions that the deictic demonstrative pronoun 'this' has many deep indications:

1. Joseph does not want to discuss the details of his old dream nor what is happening right now.

2. It also means the decrease of the volume of Joseph's voice, after he is raising it saying '0 my father' who turns his face towards him and continues 'this is ...'.

3. It indicates that his father is closer to him more than his other brothers (p. 65).

Forgiveness comes from Allah when we acknowledge and ask forgiveness just like when the brothers finally realize how gravely wrong they are to lie to their father before about the truth behind Joseph's disappearance. Jacob may have forgiven his sons well ahead than Joseph does for his brothers. They have recognized that forgiveness is not an option but Allah's command. The doctrine of the sovereignty of Allah means that whatever evil is committed against us has been designed by Allah to come into our lives for a purpose that is good. In the final analysis, Joseph is blessed much more before and after his trials have ended. Behind his enemy is a loving Allah who brings affliction and suffering into his life for his good and His glory.

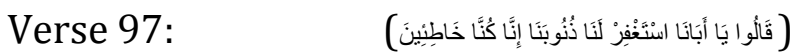

They said: "0 our father! Ask for us forgiveness For our sins, for we Were truly at fault."

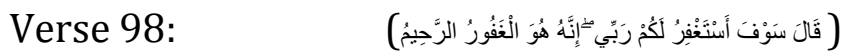

He said: "Soon will I ask my Lord for forgiveness For you: For He is indeed Oft-Forgiving, Most Merciful." (p. 586)

But one thing is certain, Allah wills that his father Jacob survives this old age to see his favorite Joseph alive once again.

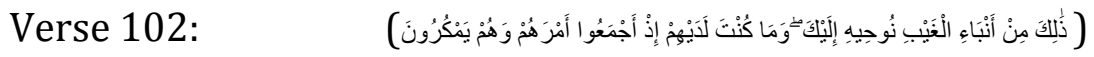


Such is the one of the stories Of what happened unseen Which We reveal by inspiration Unto thee: nor wast thou (Present) with them when they Concerted their plans together In the process of weaving their plots. (p. 588)

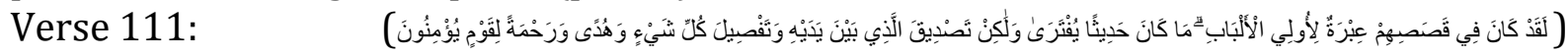

There is, in their stories, Instruction for men endued With understanding. It is not A tale invented, but a confirmation of what went before it,-A detailed exposition of all things, and a Guide And a Mercy to any such As believe. (pp. 590-1)

Context: Alah above all, the real Author

- Representamen

: revelation through the last Prophet Mohammed

- Object

- Interpretant : the story of Joseph as revealed time so that there may be salvation and restoration. The blessings come to all righteous and who obeys Allah. The testimonies are evident and it's only by faith as one of the pillars of Islam that we grow and mature on our belief of the oneness of Allah.

The story of Joseph has been retold to prophet Mohammed as confirmation of what he knows and makes possible as revealed by Allah so that what has been lacking will become complete. For the Seekers after Truth, that the Story of Joseph with his brothers are Signs.

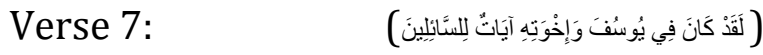

Verily, in Joseph and his brethren Are Signs (or Symbols) For Seekers (after Truth). (pp. 551-2)

\section{CONCLUSION}

After all the readings and re-interpretation of Qur'anic version of the story of Joseph, we courageously affirm that it is well worth our time particularly the legacy he has left behind. It is a story within a story as we learn every bit of Joseph's life from beginning to the end. But the message is clear, first and foremost it demonstrates Allah's sovereignty, His complete control over peoples lives and over everything. This could be manifested through the faith we have on the Almighty Allah, the Omnipotent, Omniscient and Omnipresent. This is a story of leadership, righteousness, forgiveness, justice, vindication, victory, redemption, restoration and love that only Allah can give. The patriarch Jacob's family is restored due to the love shown by Joseph who remains the driving force why they are once again reunited. The main there here is love, not just ordinary but unconditional love.

Again, we can reasonably ask ourselves, what's so important about Joseph that he should get one chapter (12) in Qur'an devoted to the ups and downs of his life? The story of Joseph forms an important bridge between the patriarchs (Abraham, Isaac and Jacob and Moses. The story shows us how and why the people of Israel has got to Egypt in the first place, the big plan of salvation of mankind through deliverance from famine and oppression, until the time Moses has confronted Pharaoh and commanded him to 'Let my people go.'

The story is retold by Allah to Prophet Mohammed at an opportune time to affirm oneness of Allah. It is narrated as a revelation, an inspired word of Allah for all at a time when people are divided in their belief. Thus, there are several moral lessons learned and spiritual wisdom that have been unveiled in front of our very eyes. Notice in the story that there's no mention of any name of the ten half brothers except with that of Benjamin, his full brother. This is made possible in order to focus the story on the actions and lives of Joseph in particular, and how made him victorious in general. 
This is one of the reasons why undertaking this research is worth our time and effort. We could never capture the richness and beauty of the words in Qur'an though we believe that we are guided in providing relevant analysis as revealed through the signs. The significance is that we give particular new insights upon reflection, observation, interpretation and application on selected verses of the story of Joseph.

To sum it all, this is a story where the legacy of prophet Joseph will remain forever, while serving as an inspiration and encouragement for those whose lives are affected and undergoing similar situation. That the sovereign will of Allah prevails no matter what circumstances we are in is one proof that Our Creator takes care of us. That we should not give up on living and loving as well. That Allah is in complete control of everything, our troubles and sorrows will just fade if we remain calm and listen to what our Allah says through our heart. That Allah Who is All-Knowing, All-Wise can confer His blessings to all who obey.

What has started as a dream ended in fulfillment of all the dreams that come after Joseph first dream. Nothing has been missed out. For with Allah, there's nothing difficult nor impossible. And most of all, Joseph's story has shown and guide us to the Monotheism belief in Allah.

\section{BIBLIOGRAPHY REFERENCES}

Abū Ḥamdah, M. A. Fī al-tadhawwuq al-jamālī li-sūrat Yūsuf : dirāsah naqdīyah ibdā'īyah. Oman: Dar Al-Bashir, 1985.

Ali, A. Y. The Holy Qur-ān: English Translation \& Commentary (With Arabic Text) (1st ed.). Kashmiri Bazar, Lahore: Shaik Muhammad Ashraf, 1934.

Al-Qurashī. Binyat al-ru'yā : al-lughah wa-al-dalālah wa-binā' al-shakhṣīyah

fī qișșat Yūsuf. Yemen: Ministry of Education \& Tourism, 2004.

Brandt, P. A. 'Deixis - a semiotic mystery: Enunciation and reference'. Cognitive Semiotics. 9: 1 (2016), 1-10.

Bopry, J. 'Semiotics, Epistemology, and Inquiry'. Retrieved from

http://www.und.edu/dept/ehd/journal/Fall2002/bopry.html , (2002).

Chandler, D. Semiotics: The Basics. Routledge: London \& New York, 2007.

Chatman, S. 'Story and Narrative'. In Dennis, W. (ed.) Literature In the Modern World: Critical Essays and Documents. New York: Oxford University Press, 2004, pp. 120-8.

Dennis, W.(ed.). Literature In the Modern World: Critical Essays and Documents (1st ed). New York: Oxford University Press, 1990.

Dennis, W. (ed.). Literature In the Modern World: Critical Essays and Documents (2nd ed.). New York: Oxford University Press, 2004.

Eco, U. A Theory of Semiotics. Bloomington: Indiana University Press, 1976.

Eco, U. From the tree to the labyrinth: Historical studies on the sign and interpretation. Cambridge, MA: Harvard University Press, 2014.

Gaines, E. 'Everyday Semiotics: The Paradox of a Universal Discipline'. The American Journal of Semiotics 31.3-4 (2015), 295-310.

Gaspard, J. 'Discourse analysis with Peirce? Making sense of discursive regularities: The case of online university prospectuses'. Semiotica; 207 (2015), 551-565

Gorny, E. . 'What is Semiotics?' Retrieved from http://www.zhurnal.ru/staff/gorny/english/semiotic.htm.

Hawkes, T. Structuralism and Semiotics. London: Routledge, 1977.

Hilpinen, R. 'Conception, sense, and reference in Peircean semiotics'. Synthese, 192, (2015), 991-1018.

Hoffmeyer, J. 'Introduction: Semiotic Scaffolding'. Biosemiotics. 8, (2015), 153-158. 
Ivković, D. 'Towards a semiotics of multilingualism'. Semiotica. 207, (2015), 89-126.

Jappy, T. Regards sur le poème muet. Perpignan: Presses Universitaires de Perpignan, 2010.

Jensen, T. W. \& Pedersen, S. B. 'Affect and affordances - The role of action and emotion in social interaction'. Cognitive Semiotics 9: 1 (2016), 79-103.

Metro-Roland, M. 'Interpreting Meaning: An Application of Peircean Semiotics to Tourism'. Tourism Geographies Vol. 11, No. 2 (2009), 270-279.

Nöth, W. \& Jungk, I. 'Peircean visual semiotics: Potentials to be explored'. Semiotica 207 (2015), 657-673.

Nuessel, F. 'Review article: Interpretive semiotics'. Semiotica 169-1/4 (2008), 343-360.

Ogden, L. 'What is the difference between the Semiotics of Saussure and Peirce?'. Retrieved from https://www.quora.com/What-is-the-difference-between-the-Semiotics-of-Saussure-and-Peirce/answer/LianaOgden.

Peirce, C. S. The collected papers of Charles S. Peirce, 8 vols., C. Hartshorne, P. Weiss \& A. W. Burks (eds.). Cambridge: Harvard University Press, 1931-1966. [Reference to Peirce's papers will be designated CP followed by volume and paragraph].

Peirce, C. S. The writings of Charles S. Peirce: A chronological edition, Vol 1-6, 8. Peirce Edition Project, editor. Bloomington: Indiana University Press, 1982.

Petrilli, S. and Ponzio, A. Semiotics Unbounded: Interpretive Routes Through the Open Network of Signs. Toronto: University of Toronto Press, 2005.

Queiroz, J., Emmeche, C. \& El-Hani, C. 'A Peircean Approach to 'Information' and its Relationship with Bateson's and Jablonka's Ideas'. The American Journal of Semiotics 24.1-3 (2008), 75-94.

Saussure, F. de. Course in General Linguistics (trans. Roy Harris). London: Duckworth, 1916/1983.

Sebeok, T. (ed.). Sight, Sound, and Sense. Canada: Thomas A. Sebeok, 1978.

Tobin, Y. Semiotics and Linguistics. England: Longman Group UK limited, 1990. 